\title{
The Integration Strategy of Conservation Values in Habituation of Semarang State University Campus
}

\author{
Saddam $^{1}$, Achmad Zurohman ${ }^{2}$, Babul Bahrudin ${ }^{3}$ \\ ${ }^{1}$ Civic Education Department, University of Muhammadiyah Mataram, Indonesia \\ ${ }^{2,3}$ Tadris Social Sciences, Institute of Islamic Sciences of Zainul Hasan Genggong, Indonesia \\ 1'saddamalbimawi1@gmail.com, ${ }^{2}$ dzurohman50@gmail.com, ${ }^{3}$ babulbahrudin@gmail.com
}

\begin{abstract}
ABSTRAK
Keywords:

Integration;

Conservation Values;

Habituation.

UNNES crowned a conservation university. The vision of UNNES to 2040 became an internationally reputable and conservation university. Conservation means the effort to protect and preserve the value of culture and human behavior in interacting with the environment. The research objectives reveal the integration of conservation values in UNNES campus habituation. The study used a qualitative case study design. Data collection using observations, documentation, and interviews. Testing the validity of data using the triangulation of sources, techniques, and theories, using the social action theory Talcott Parsons and the personality theory of Gordon Allport. Data analysis uses the Miles and Huberman models through three stages; Data reduction, data presentation, and data verification, as well as Spradley's taxonomy analysis. The results of the integration strategy of conservation values in the habituation of UNNES campus are conducted through academic and non-academic activities. Through academic activities, it is seen from the planting of conservation values through conservation education, environmental education, and other courses. While through non-academic activities are seen with the planting of conservation values through UPT conservation development activities, student activity units, and the Student Activities Center. The student personality has been conservative seen from the conservative behavior of college students, habituation to be a strategy to embed conservation values. With this, the student's behavior is closely related to the conservation character he has, so it can reflect the actions that have been performed by the role of instilling the conservation values of UNNES.
\end{abstract}

Article History:

Received: 22-06-2018

Revised : 12-08-2018

Accepted: 28-08-2018

Online : 30-08-2018

\section{(c) (1) (2)}

This is an open access article under the CC-BY-SA license

Crossref

https://doi.org/10.31764/ijeca.v1i2.2124

\section{A. INTRODUCTION}

The college has an important role in building the next generation in the nation and state life. The important role is to educate and prepare the next generation sustainably to achieve national objectives. National objectives as mandated in the fourth paragraph of the opening of the Constitution 1945 the Republic of Indonesia, namely "protecting all the nation of Indonesia and all the blood in Indonesia and to promote the general welfare, educate the life of the nation, and participate in the order of the world based on independence, eternal peace, and social justice,". Education and teaching organized by the college are one of the efforts to educate the life of the 
nation to promote General affairs. This is done by forming the next generation of nations and countries that are ready and skilled to realize Indonesia's national goals and development.

Article 1 Number 1 Law number 20 of 2003 mentions education is a conscious and planned effort to create a learning atmosphere and learning process so that students actively develop their potential to possess spiritual power of religion, self-control, personality, intelligence, noble morality, and skills necessary to himself, society, nation, and state (Indonesia, 2003). These institutions (Institute of Education) as a container that will shape the personality of the nation, built from theories and academic field practices that are prepared directly to be in the field of the social world (Saddam, Setyowati, \& Juhadi, 2016). Thus the role of the educational institution is very decisive as to what and how the future of the nation and the country through the preparation and preparing the next generation of the nation. Similarly, UNNES (State University of Semarang) as one of the higher education institutions under the auspices of the Ministry of Education and Culture of the Republic of Indonesia, which is a generation and skilled personnel as the successor of the nation and state.

UNNES is one of the colleges that has established itself as a conservation university and has a conservation brand. "Conservation University" is defined as a university where the implementation of Tri Dharma Perguruan Tinggi is based on conservation principles, including actions to protect, preserve, and utilize natural resources, ethics, art and culture (Riki, 2014) and (Setyowati, 2015). The conservation itself has the meaning of protecting and preserving the cultural value and human behavior in interacting with the environment. The conservation Brand also became the vision of the development of UNNES up to 2040, which is to realize UNNES as internationally reputable conservation and reputable university. The conservation insight has the meaning of perspective and behaves in the principle of conservation, namely the protection of life-buffer systems; Preservation and utilization of natural resources (SDA), environmental balance and social, artistic and cultural values. The principle of conservation is a cornerstone of conservation-based campus governance that is realized through the seven pillars of the conservation university, namely; 1) Biodiversity conservation, 2) green architecture and internal transportation system, 3) waste management, 4) paperless policy, 5) clean energy, 6) The conservation of ethics, art, and culture, 7) The caderiration of missed, and also realized through the eight values of UNNES conservation.

UNNES develops eight conservation values, namely inspiring, humanistic, caring, innovative, sportsmanship, creative, honesty, justice. The conservation values are implemented for all academics, especially students (Setyowati \& Eko Handoyo, 2019). Conservation is not only understood in the physical context but also understood as a value (non-physical) that needs to be developed continuously (Saddam et al., 2016). Conservation is a complex and ongoing process involving a determination of what is viewed as inheritance, how it is guarded, how it is used, by whom, and for whom. The inheritance mentioned in the definition does not only concern the physical but also the cultural (Richmond, Bracker, \& Bracker, 2009). Conservation values are a habituated value in the UNNES environment, more moral and social values. This can be done with habituation supported by the environment and residents of UNNES. Habituation is used for a good purpose for human development that has character, in this case, related to the development of Unnes and its academic society as a conservation university. UNNES continues to improve the application of conservation aspects by encouraging conservation actions and ethics and building green campuses through environmentally friendly buildings, waste management, energy-efficient, solar energy panels, wastewater treatment, and conservation plans.

Based on the above, researchers are interested in excavating and expressing the integration of conservation values in UNNES campus habituation. Researchers uncover how the UNNES brand of conservation can thrive and grow in more college citizens. The student personality of Unnes is closely related to the conservation character he has, so it will be seen the action in integrating UNNES conservation values by the participating parties. 


\section{B. METHODS}

The study used a qualitative case study design. Use qualitative case studies to explore typical phenomena that exist only in UNNES. With this researchers excavate, photograph, and reveal the strategy of integration of conservation values in UNNES campus habituation. The focus of this research is the strategy of integration of conservation values in UNNES which include; Curricular and extracurricular activities related to the conservation of UNNES.

The source of the research data is obtained through the informant, event or phenomenon that researchers observe, and the source of the document is available. The determination of informant using purposive sampling, with the criteria of the informant that understands the conservation of UNNES, characterized by the ability to provide information, is still actively involved in conservation activities, and the informant that conveys what information is. Based on these criteria the informant researchers gained in the research was head of the UPT conservation Development, 3 lecturers of conservation groups, 8 lecturers of Faculty of Faculties of each faculty in the strata program I UNNES and 31 students who have pursued the course of conservation education from all faculties, with details 3 students of Faculty of Education, 5 students of the Faculty of Social Sciences, 3 Faculty of Law students, 3 students of the Faculty of Health Sciences, 4 students of the Faculty of Languages and Literature, and 4 students of the Faculty of Mathematics and Natural sciences. Researchers conducted observations directly from the phenomenon in the field, this was done to obtain physical and nonphysical conservation data in UNNES. The Data that researchers acquire include the strategy of integration of conservation values in students, the conservation behavior of students in their daily life in the campus, student interaction with students, students with lecturers, and students with other campus residents in the campus environment. Researchers conducted more or fewer observations over two months including when conducting research interviews. For the source of documents that researchers acquire in the form of drawings related to the conservation values of Unnes, regulation of the rector of UNNES number 22 the year 2009 about UNNES as a conservation university, and books that are the holding of the citizens of UNNES in implementing the value and behavior of UNNES conservation. Documents in the form of the Book of the development of inspiring characters, the guide Book of Humanist Conservation University, the guide book on Strengthening social conservation, the innovative character handbook for Conservation Boosters, the Conservation Handbook for the University of Conservation, the pillar of Honesty University Conservation Handbook, and the University's Pillar of Justice Handbook. These books are the works and from the development of the conservation value of each faculty in UNNES which is in the brand of faculty, one value of one faculty as a characteristic.

Data collection techniques using observation, documentation, and interviews. The legitimacy of data using source triangulation, technique triangulation, and triangulation theory. The theory used in this study was the social action theory of Talcott Parsons (Parsons, 1949) And the personality theory of Gordon Allport (Allport, 1960) and (Hall, Lindzey, \& Campbell, 1957). The social action theory developed by Talcott Parsons was used to analyze the strategy of integrating conservation values in Unnes ' campus habituation. The personality theory developed by Goldon Allport is used to analyze the conservation personality of UNNES students in campus environments. Data analysis techniques using technical analysis of data from Miles and Huberman of qualitative data analysis are conducted through three phases; Data reduction, data presentation, and drawing conclusions or verifying data (Miles \& Huberman, 1994).

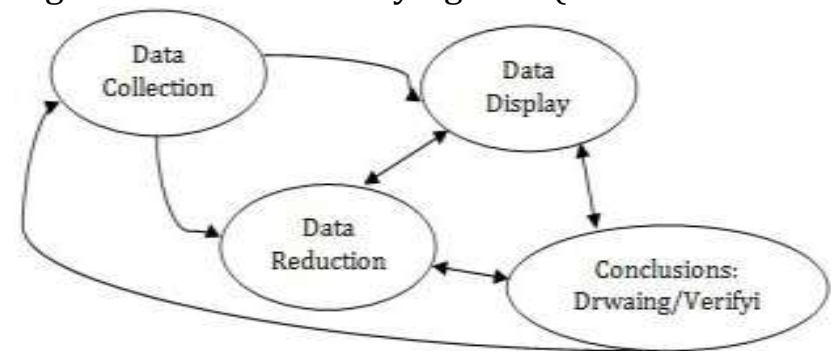

Figure 1. Interactive Model of Data Miles and Huberman analysis (Rachman, 2011) 
Researchers also used the taxonomy analysis model of Spradley. Taxonomy analysis is an analysis of the total data collected based on the domain that has been assigned a cover term by researchers can be described in more detail and depth through this analysis (Spradley, 2006). Researchers ' taxonomy analysis results are presented in the form of box diagrams and outlines. Diagram box as in Figure 2.

\begin{tabular}{|c|c|c|c|c|c|c|}
\hline \multicolumn{7}{|c|}{ COVER TERM } \\
\hline \multicolumn{3}{|c|}{ A } & \multirow[t]{4}{*}{ B } & \multirow[t]{4}{*}{ C } & \multicolumn{2}{|c|}{ D } \\
\hline 1 & 2 & 3 & & & 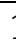 & 4 \\
\hline & & & & & & \\
\hline & & & & & & \\
\hline
\end{tabular}

Picture 2. Box Diagram by Spradley (Spradley, 2006).

\section{RESULT AND DISCUSSION}

Based on the findings data researchers get in the field about the strategy of integration of conservation values in the habituation of UNNES campus. From the interview to the 43 informants consisting of 31 students from various faculties, 11 lecturers, and the head of UPT conservation development, obtained the findings data. From 31 informant students, 1 student informant expressed a different opinion, while 30 other informants give the same core statement. The different statements from Somali Faculty of Language and art students semester VIII when researchers allowed elaborating on what conservation activities were ever followed while in Unnes, following his statement.

I am in the arts majoring in art, so alhamdulillah I dabbling in the art of dance, here the culture is still held high is still recognized by the university.... In Sinikan there is a name UKM, the process is similar to other UKM that there are filing funds, arranging programs and organizing programs (interviews with Sobali).Pernyataan Sobali di atas menunjukkan bahwa strategi integrasi nilai-nilai konservasi hanya terjadi di UKM-UKM (Unit Kegiatan Mahasiswa).

The integration of conservation values in SMEs leads to a strategy of integration in extracurricular activities, while 30 other informants say the same essence as when the researcher provides an opportunity to describe the explanation about the same, namely the activities are diverse but show their integration strategy through academic and non-academic or extracurricular and curricular activities. As with the statement Chusna one of the students of the Faculty of Economics (FE) semester VI when given the opportunity to elaborate explanations about any conservation activities ever followed while in Unnes, Chusna gave the statement that.

I am active in Mahapala mas students of nature lovers, so if for conservation often participated in involvement in UPT conservation activities. If there is a course of environmental education (PLH), only now it's college has changed its name so the conservation education course for MKU University for Children's early semester (interview with Chusna).

Referring to the above interview passages and the core of the statements of various informers, it can be stated that conservation is an act or effort to maintain, preserve, protect, and utilize the natural environment sustainably including culture and morals. However, in its development, it needs to be owned, maintained, and preserved sustainably through the process of education. As for the strategy of integration of conservation values in the habituation of UNNES campus, many informants state through curricular and extracurricular activities. Curricular activities conducted through lectures and extracurricular processes conducted through the activities of student organizations and activities for students both by faculty, conservation units, and universities. 
Head Informant UPT Conservation Development provides the core statement of strategy integration values in Unnes is done by forming the citizens of Unnes to be familiar with conservation values. The strategy of integration is conducted through conservation activities organized by technical institutions in the field of conservation known as UPT Conservation development, academic activities, and also non-academic activities. This is as stated by the informant that.

We are supporting the activities of the field of education, research, and community service. Especially for the students, we support about embedding the conservation values for the conservation cadres, then the conservation cadres are included lecturers, personnel of grief, and also students. There is an activity for education that can be through socialization, socializing through various media that can be used, can be banners, can use anything, other social media and so on. Then Ectrurricular and interarticular activities (interview with Kusmuriyanto).

Furthermore, the informant of the lecturer gives the same core statement that the conservation values integration strategy is carried out through the activities of lectures and activities outside the lecture, the process of internalizing value to shape the attitude, as said one of the lecturers of the Conservation Education College who also served as the Dean of the Law faculty that.

... In the educational process, the value of correct can not be given and then to the external, there is a process. Well, the process of internalizing that value all three must be met, cognitive means he should have insight, knowledge of what is the value of conservation, why people should learn, then forms that's just about anything he should have this. Then he must believe that it is right through attitude. Then, in the student organization, the units of activities based on the value of.... The Maghrib was an activity of student studies, so there is Asmaul Husna, Tahlil, Yasin, this is the newly completed student activities music in front of here. (Interview with Rodiyah).

Table 1. Conservation Values Integration Strategy

\begin{tabular}{|c|c|c|c|}
\hline \multirow{2}{*}{ No } & \multicolumn{3}{|c|}{ Conservation Values Integration Strategy } \\
\hline & Activities & Types of activities & Instilled value \\
\hline \multirow[t]{3}{*}{1.} & Curricular & $\begin{array}{l}\text { Courses in environmental } \\
\text { education }\end{array}$ & $\begin{array}{l}\text { RPS, lecturing process (material and duty), } \\
\text { and evaluation. }\end{array}$ \\
\hline & & $\begin{array}{l}\text { Academic Level } \\
\text { conservation Education }\end{array}$ & $\begin{array}{l}\text { RPS, lecturing process (material and duty), } \\
\text { and evaluation. }\end{array}$ \\
\hline & & Other courses & $\begin{array}{l}\text { Eight grades and eleven character } \\
\text { conservation Unnes, as well as simplicity, } \\
\text { wisdom, and togetherness. }\end{array}$ \\
\hline \multirow[t]{3}{*}{2.} & Extracurricular & $\begin{array}{l}\text { UPT Conservation } \\
\text { development Activities }\end{array}$ & $\begin{array}{l}\text { Seven Pillars, eight grades, and eleven } \\
\text { character conservation Unnes. }\end{array}$ \\
\hline & & $\begin{array}{l}\text { Student activity Unit } \\
\text { Activities }\end{array}$ & $\begin{array}{l}\text { Principle of seven Pillars, eight grades, and } \\
\text { eleven characters of Unnes conservation, as } \\
\text { well as simplicity, wisdom, and togetherness. }\end{array}$ \\
\hline & & $\begin{array}{l}\text { Student Activity Center } \\
\text { Activities }\end{array}$ & $\begin{array}{l}\text { Principle of seven Pillars, eight grades, and } \\
\text { eleven characters of Unnes conservation, as } \\
\text { well as simplicity, wisdom, and togetherness. }\end{array}$ \\
\hline
\end{tabular}

Source: Research Data.

In Table 1 above shows several ways of integration of conservation values through curricular and extracurricular activities as habituation with the availability of conservation areas in UNNES. Integrating conservation values through curricular activities is conducted through the process of teaching and learning in environmental education courses, conservation education, and other courses. Where in the course of environmental education and conservation education instilled seven pillars of conservation, eight conservation values, and eleven character 
conservation UNNES, while for other subjects the principles of conservation and conservation values are planted in the course of the lecture, the introduction, assignments, and evaluation. The strategy of integration of conservation values through extracurricular activities is conducted through activities in UPT conservation development, student activity Unit (UKM), and Student Activity Centre (PKM). The student organization, guided and directed directly by the lecturer and the cooperation with the activities is an effort to establish the academic skills to adhere to the principle of conservation, to destroy all citizens of UNNES. Where in this extraarticular activity instilled the principle of seven pillars, eight grades, and eleven characters of Unnes conservation, as well as the value of simplicity, wisdom, and togetherness.

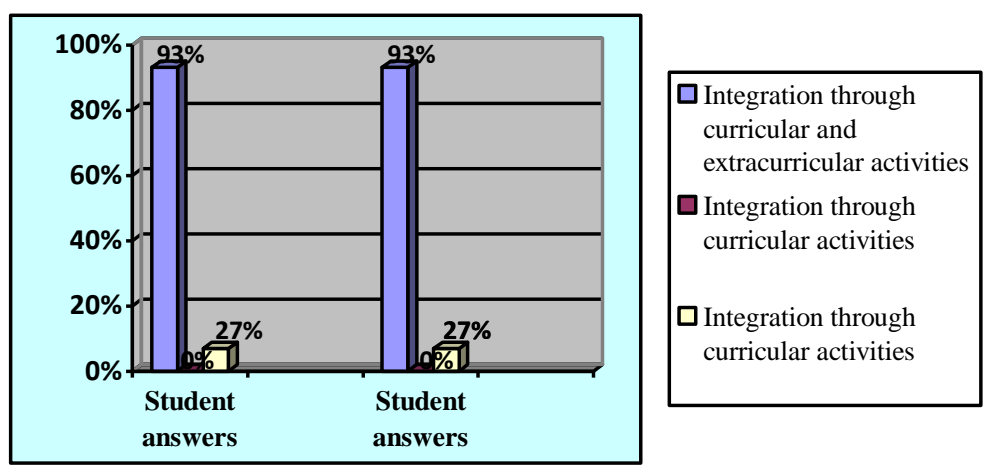

Figure 3. Percentage of conservation Values integration chart

In Figure 3 to demonstrate the planting of conservation values through curricular, extracurricular, and curricular activities. From 31 informant statements 93\% said that the integration of conservation values in Unnes was carried out through curricular and extracurricular activities, $7 \%$ said through extracurricular activities only, and $0 \%$ through curricular activities only. With this, Unnes ' conservation values are integrated through curricular and extracurricular activities.

Based on the above, the strategy for integration of conservation values is carried out through curricular and extracurricular activities. Through curricular activities instilled in the course of courses specialized in environmental education, conservation education, and other subjects, while through extracurricular activities instilled through activities in SMES, PFIS, and activities in UPT conservation development. The existence of UPT conservation development Unnes is a technical institution that supports educational activities, research and community service. Unnes himself sought a pattern of habituation of conservation values to be embedded in students, thus forming a student of conservation character through academic activities and non-academic activities. This process almost happens in all activities in all opportunities in the campus environment, thus bringing and familiarizing all the citizens of Unnes to act on the principle of conservation.

\section{Strategic integration of conservation values in curricular activities}

Based on the findings data of the deep interviews the researchers did to the informers on how the strategy of integration of conservation values in the campus habituation linkages with the implementation in curricular activities. From the interview to the 43 informants consisting of 31 students from various faculties, 11 lecturers, and the head of UPT conservation development, obtained the findings of the researchers concluded as follows.

Informant researchers use from in-depth interviews with lecturers and head of UPT conservation development. When researchers asked how the strategy of integration of conservation values in the campus habituation was related to the implementation in curricular activities. From various answers can researchers say the integration of conservation values through curricular activities is applied to the efforts of planting value, habituation of value and good example. One of the ways in Unnes is the integration of conservation values through 
lecturing activities. The activities in the planting of conservation value are manifested in conservation education courses and other subjects related to the planting of conservation values, moral values, and characters that can form student personalities. This is in addition to being planted through a special course of conservation education also planted through other subjects. As stated by one of the following lecturers, who served as deputy Dean of the FIP academic field, that.

If the activities, of course, are related to the opportunity, every opportunity there, the lecturer gave the lecture should inspire other than discuss the lecture material inspiration despite the various kinds of things including inspiring to be a good person, to have a good character is to be in inspiration, it is all a planting value (interview with Purwanto).

The next informant is one of Unnes ' active lecturers and plays an important role in conservation activities including the drafting of books on the character of conservation. When researchers inquire about the same thing, the following statement is said that "there is an education in the environment, if conservation education used to be the education of the environment is two and 2 credits" (Interview with Handoyo).

The subsequen't informant of the head of the UPT conservation development Unnes, when researchers asked the same, the following statements are obtained.

There is a course if the PLH is now changing the conservation course. From there we can convey the messages of conservation, it is not only the course of the subjects but other courses and we also hope each faculty, the head of Prodi at least can develop a special course following the Prodi (interview with Kusmuriyanto).

The learning process in the lecture is the same as usual, where lecturers prepare the components to be used in learning, and then perform stages in the learning process. The components typically created by lecturers are semester learning Plans (RPS) and lecture contracts, while stages in learning include preparation, implementation, and evaluation. It is as a statement of one of the lecturers of conservation education courses who also served as the Dean of $\mathrm{FH}$, that.

"The lecture process is the same, so there is preparation, implementation, evaluation, and students interacting.... internalize that value through three main processes that must be met i.e. cognitive, affective, and psychomotor. Therefore the way to give it is through the learning process, learned that there is a knowledge transfer process, there is an internalization of value, it is in the form of analysis of behavior attitude example from students and their prayers and all the components in the Unnes both institutionalinstitutional, regulations, then the human, the values that are developed, then they must also manifest in the daily life (interview with Rodiyah).

The following informant researchers take from students, student informants that amounted to 31 students from eight faculties have almost the same opinion, only one difference. From 31 informant students, 1 student informant expressed a different opinion, while the 30 other informants gave a statement of the same essence when the researcher asked how the strategy of integration of conservation values in the campus habituation related to implementation in curricular activities. The different statements from wvSobali student FBS VIII semester which suggests that the strategy of integration of conservation values only occur in UKM-UKM only. This illustrates that the integration strategy according to the informant occurs only in extracurricular activities. While 29 other informant says the same essence when given the opportunity to describe the explanation of the same, namely the activity is conducted and carried out through the process of lectures as usual, both through a special course of conservation education and also other courses in which integrated conservation values. As with one statement by the Faculty of Law (FH) in semester IV when the same question was expressed, his statement that "a lecture on moral planting/moral education is often taught how to form morals and there is a public course of environmental education" (interview with Supriyadi).

Referring to a few excerpts of the above interviews and based on the documents that researchers get then can researchers say the integration of conservation values is carried out through the course of lectures as usual, both through a special course of conservation education 


\section{I IJECA (International Journal of Education and Curriculum Application)}

Vol. 1, No. 2, August 2018, pp. 01-13

and also other courses in which integrated conservation values. Planting conservation values through academic activities coupled with the integrity of awareness of the importance of the value, so there is a special course on conservation for students. These documents are prepared as a step to integrate conservation values in a conservation education course or through curricular activities. Integration is the process of mixing, combining to be one-unified unity, the integration of conservation values in campus habituation that is one of them through curricular activities means combining conservation values in the concept of habitation for students through lecturing activities.

Preparation or planning is a factor that plays an important role in implementing learning. To be able to create a conducive condition in the learning process and encourage students to be able to master several academic competencies as contained in the semester Learning Plan (RPS). Lecturer in Conservation Education course before starting the process of learning to teach further the day to be able to prepare as well as possible everything needed in the learning process. After the subsequent preparations are the implementation, implementation of the integration of conservation values through learning activities using the reference RPS. RPS is a basic reference and handbook for lecturers integrating conservation values during the learning process.

The teaching and learning process in the classroom, this process as one of the strategies used for planting conservation values in students. Next is the evaluation phase, at this stage of evaluation of the learning process. At this stage evaluation from the initial process to the end of the study, from the materials that have been given, learning practices, and other models in the learning process. This is to determine the student's level of understanding, mastery, and ownership of the values instilled in the learning process.

Table 2. Strategic integration values in curricular conservation values

\begin{tabular}{|c|c|c|c|}
\hline \multirow{2}{*}{ No } & \multicolumn{3}{|c|}{ Integration of conservation values in curricular activities } \\
\hline & Courses & Integration through & Materials/Characters implanted \\
\hline 1. & $\begin{array}{l}\text { Environmental } \\
\text { education }\end{array}$ & $\begin{array}{l}\text { Preparation or } \\
\text { planning, } \\
\text { implementation, and } \\
\text { evaluation }\end{array}$ & $\begin{array}{l}\text { Basic environmental concepts, understanding of } \\
\text { environmental conservation, and the scope of } \\
\text { conservation education } \\
\text { Environmental issues } \\
\text { Seven Pillars of Conservation } \\
\text { Eleven character conservation } \\
\text { Principle of conservation value }\end{array}$ \\
\hline 2. & $\begin{array}{l}\text { Conservation } \\
\text { education }\end{array}$ & $\begin{array}{l}\text { Preparation or } \\
\text { planning, } \\
\text { implementation, and } \\
\text { evaluation }\end{array}$ & $\begin{array}{l}\text { Basic environmental concepts, understanding of } \\
\text { environmental conservation, and the scope of } \\
\text { conservation education } \\
\text { Environmental issues } \\
\text { Value Conservation } \\
\text { Resource Conservation } \\
\text { Seven Pillars of Conservation } \\
11 \text { Character Value Conservation }\end{array}$ \\
\hline 3. & Other courses & $\begin{array}{l}\text { Preparation or } \\
\text { planning, } \\
\text { implementation, and } \\
\text { evaluation }\end{array}$ & $\begin{array}{l}\text { Implanted the eight principles of conservation } \\
\text { value. }\end{array}$ \\
\hline
\end{tabular}

Source: Research Data

In Table 2 shows that the strategy of integrating conservation values in curricular activities is conducted through a lecture process. The process begins with preparation or planning, implementation, and evaluation. This strategy is conducted on specialized courses in conservation education, environmental education, and other subjects. In other courses instilled principles of non-concept conservation values, such as inspiring, honest, disciplined, humanist, innovative, and others. 


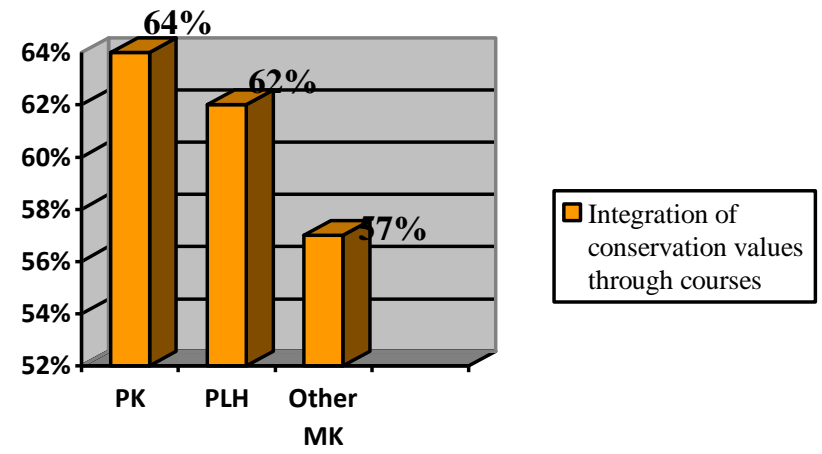

Figure 5. Percentage of conservation values integration in curricular activities

In Figure 5, shows the percentage of conservation values integration in curricular activities through the course of conservation Education (PK), environmental Education (PLH), and other courses (MK other). Referring to the research data of the 43 informants consisting of the head of UPT conservation development, 11 lecturers, and 31 student informants. From the overall statement of the informant, $64 \%$ said the integration of conservation values through the course of conservation education, this is because the course is only obtained by students from 2014 to the student force of 2010 . Furthermore, $62 \%$ said through environmental education courses, because the course is intended for students from generation 2015 to above. While 57\% said through other subjects. The low percentage of conservation values integration through other subjects is because other subjects focus on their respective scientific fields. However, in the course of other subjects the principles that lead to the conservation values implicitly already exist. The statement is based on the semester level, for students from 2015 to above in obtaining a conservation education course, while students from 2014 to the bottom get a course of environmental education. In addition, some informant is also integrated through other subjects through the principles of conservation values and also the special course of conservation.

Based on RPS documents that researchers get that the conservation education courses provided include the basic environmental concepts, the understanding of environmental conservation, and the scope of conservation education. Environmental issues: Global, national, and local environmental issues. Conservation value: Paradigm and environmental ethics; Character values, conservation behaviors, cultural conservation, and conservation cauterization. Resource Conservation: Natural resources, non-biological and biological natural resource conservation. Conservation of green architecture, clean energy, and green transport. Conservation of waste and paperless management.

Thus, the planting of conservation values through curricular activities is more geared towards habituation of the principles of conservation values during the course (planning, implementation, and evaluation) of either the special courses of conservation education or the anciency of environmental education as well as other subjects. The strategy of integration of conservation values is carried out from the preparation of the lecture, the implementation in the lecture, and the evaluation of the lecture process as a benchmark, and then seen how students interact with the conservation and habituation materials that have been obtained at the lecture process. The third process of the plot became a strategy for planting conservation values, where in the RPS outlined principles on the value of conservation, more-more in the process and also evaluation.

\section{Conservation value integration strategy in extracurricular activities}

Based on the findings from the results of a thorough interview the researchers did to the informant on how the strategy of integration of conservation values in the campus habituation related to the implementation in extracurricular activities. From the interview to the 43 
informants consisting of 31 students from various faculties, 11 lecturers, and the head of UPT conservation development, obtained the findings of the researchers concluded as follows.

Informant researchers use the results of interviews with lecturers and branch UPT conservation development. Where when researchers asked how the strategy of integration of conservation values in the campus habituation related to the implementation in extracurricular activities. From the various answers can researchers say the integration of value through the Ectrecular activities directed at the student activities. The student activities are in units of student activities at the university level and the faculty level. Conservation activities in the environment of Unnes are also not separated from student roles and efforts through student activities. Conservation values are integrated when the activities are planned together, implementation of activities, and evaluation of activities. In the student organization, there are also stages of cauterization to prepare cadres that are ready to cooperate and respond to the organization. The value of caring, honesty, inspirational, fairness, discipline, humanist, deliberation, togetherness, cooperation, the responsibility in line with conservation values is always emphasized in every time there are meetings, both for the planning of activities, the process of activities and also in the associations in the community so that the students accustomed to those principles. The activity is directly in contact with the students and even society in general.

The seminar activities for student self-development. The activity is a self-development activity for students held in the auditorium Unnes. Tree planting activities in creating environmental conservation, in the Unnes itself to familiarize students concerned with the environment is done tree planting habituation at the beginning of new student admissions every year, as well as environmental care activities by students in UKM-UKM and PKM-PKM. This activity in addition to cultivating student awareness of the environment also fosters awareness, cooperation, and social life of students.

Extracurricular activities that lead to the conservation of Unnes are also integrated through activities in the Student Activity Unit (UKM) and in the Student Activities Center (PKM). At the level of UKM-UKM many activities that do have the same principle with the mission of UPT Conservation development will similarity the direction of the program. It is like the statement of one of the semester II FH students when researchers asked the same thing, that "if the group is ever dancing conservation, continue to eat with food conservation, continue the attraction for the attraction of the campus activities" (interview with Abed). Researchers also asked the same in one of the semester IV FIP students as a research informant, the statement that "the activity of making compost, activities in the community kayaking the public often, and the planting of moral value on the campus" (an interview with Kusuma). From the interview excerpts can researchers say the direction of conservation activities is more demonstrated activities conducted faculty with UPT Conservation development UNNES.

The next informant is a semester VIII FBS student when researchers ask how the strategy of integration of conservation values in the campus habituation ties to the implementation in extracurricular activities. The informant states that.

I was in art so alhamdulillah I dabbling in the art of dance or the musical art I dabbling there.

Here the culture and the value of art is held high still recognized by the university "(interview with Sobali).

From the above interview excerpts can researchers say the direction of this activity is more on cultural conservation by noting the principle of conservation values developed in UNNES. The value of conservation is integrated by lecturers and guiding certain students to be able to guide other students. 


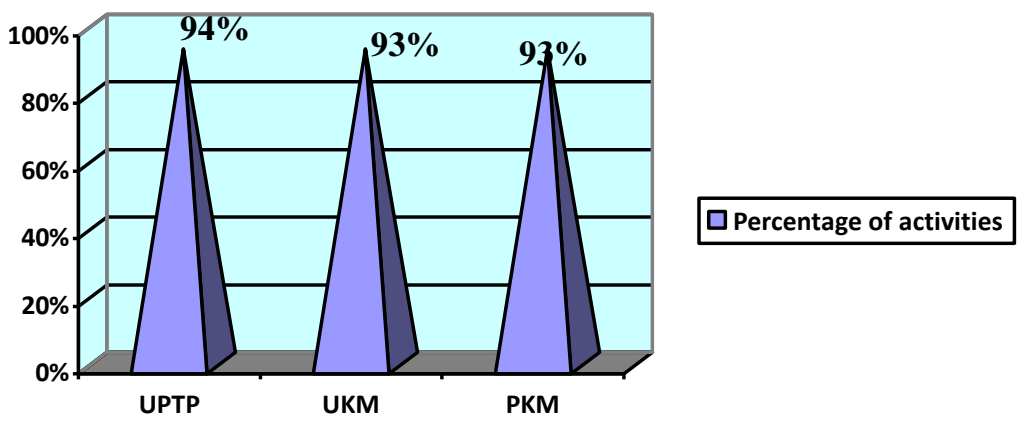

Figure 6. Percentage of extracurricular activities Student informers.

In Figure 6. Extracurricular activities that students are involved in. The integration of conservation values is carried out through student activities at the PKM level, UKM, and also activities conducted by UPT conservation development for the students. Conservation activities in the environment of Unnes are also not separated from student roles and efforts through student activities. Based on the visible graph $93 \%$ of student informant expressed the integration of conservation values conducted on activities in UKM and PFIS, it is because most of the students are active and involved in activities organized by other students in the campus environment, while $94 \%$ of student informant said conducted through the activities in UKM, PKM, and UPT conservation development, the percentage of the 30 student informant. Low percentage through activities in UKM, PFIS, and UPT conservation development because researchers dig from student informants. With this, the guide is on the data that researchers get from student informants. Conservation values are integrated when the activities are planned together, implementation of activities, and evaluation of activities. In the student organization, there are also stages of cauterization to prepare cadres that are ready to cooperate and respond to the organization.

Thus, the strategy of integration of conservation values through extracurricular activities was conducted through self-development activities on the University's Student Organization (UKM), Faculty level (PKM), and other activities held by universities or faculties that cooperate with UPT conservation development. These activities are like tree planting, compost house making, together, dancing conservation, eating together food conservation, and preserve it by upholding the value of culture and art. This is directly a flow of moral value and habituation to conservation principles in Unnes. Conservation values are integrated when the activities are planned together, implementation of activities, and evaluation of activities.

Based on the findings of data on the field and thought frameworks built using the perspective of the Social action theory Talcott Parsons. The construction of the social action theory of Parsons in the form of the concept of the functional structure of studies on the integration strategy of conservation values in campus habituation leads to the status and role of a person in a structure or system. Social change should begin with the study of the social structure first, which is explained with the premise of four functional needs, namely adaptation or adaptation (A), in which UNNES must be able to adapt by tackling the situation beyond the campus or complex community environment to form student personality according to climate and values in UNNES. Goal attainment or achievement of objectives (G), related to the way the agency Unnes regulates and maintains the relationship between the campus residents who are the components to be established relationships and good communication in managing, educating, and evaluating to achieve common objectives. Integration or integration (I), in which the social system is implemented, located at the conservation values that are denied to the scientific field of the respective study program then integrated by the leadership, lecturers, and UPT conservation development in relation to the values of conservation for the Mahaiswa. And latent pattern maintenance or maintenance of latent patterns (L), in which the way of Unnes 
institutions maintain patterns that have been patterned and improve existing patterns as cultural functions, the entire series is known as AGIL theory.

The strategy of integration of conservation values in the campus habituation of Unnes for the formation of student personalities is conducted through all lines of activity, this is not detached from curricular and extracurricular activities. As stated (Handoyo et al., 2010) that character education in UNNES is integrated with the learning process (academic) and through the development of student affairs, this is not separate but is done in an integrated. Student development in question has led to non-academic activities, contains a series of activities conducted by leaders, lecturers, and certain units for students, as well as activities by students in the PKM and UKM. The strategy of integration of conservation values through academic activities is conducted in the learning process during the lecture, where the conservation principles are planting and conservation values of the entire lecture, through introduction, assignments, and evaluation. Habituation of the principles of conservation values during the lecture in the special courses of conservation education or the former environmental education as well as other subjects. The course process is like lecturing usually, there is preparation, implementation, and evaluation so that in this process the conservation values are integrated into students with various techniques and models used in learning.

The strategy of integration of conservation values through extracurricular activities is conducted through activities of student organizations that are guided and directed directly by lecturers and in collaboration with UPT conservation development. These activities as an effort to establish the academic society to adhere to the principle of conservation, so that the citizens of UNNES habituated with conservation values. As well as self-development activities through student organizations both in UKM at the university level, faculty level, and other activities held by universities or faculties that cooperate with UPT conservation development. The activity as a non-academic step in planting the value of conservation on the main academic civil society for university students Unnes. This is directly a flow of moral value and habituation to conservation principles in Unnes. Where in the process these activities are encouraged to be inspired/inspiring, taught in deliberative, behave well against others, caring, creative, innovative, dispelling, honest, fair, and the importance of togetherness.

As the results of the research conducted Setyowati that the strategy to build the environment PGSD (elementary school teacher education) Unnes should be designed in the short, medium and long term. The implementation of non-academic and academic, physical and nonphysical conservation, visible and invisible things that should always be evaluated continuously. Dissemination of conservation Program and cadre regeneration in every unit in PGSD UNNES continues to optimally achieve the success of conservation establishment (Setyowati, 2015). Likewise, with the research findings data, the difference lies in the scope of the study where (Setyowati, 2015) researched PGSD Unnes, while the researchers themselves conducted a thorough research in UNNES.

The strategy of integration of conservation values for UNNES students conducted above is an act based on the theory of Talcott Parsons. Where social systems are implanted jointly on students and campus residents. The integration of conservation values is done in each line of activities and on all occasions are either by the university leadership, faculty, majors/departments, UPT Conservation Development, education personnel, and lecturers to students, and students to other students. The planting of conservation values is carried out by all the campus that is in the form of habituation activities as a strategy. Such habituation is done in planning activities, implementation activities, and evaluation of activities. In the series students are invited, confirmed, and used for discipline, deliberation to achieve consensus, cooperation, honest, fair, inspiring, innovative, thoughtful, religious, creative, sportsmanship, and the meaning of cooperation.

The social system is integrated to achieve the objectives of the character of conservation in students into a socially conservative social culture and natural environment, as stated (Dwidjoseputro, 1994) that the integration means in the management of resources is integrated with various interests so that there is no harm to the other. The adaptation was conducted from 
the beginning of the Unnes neighborhood students to be introduced to the academic system, campus climate, and also the campus environment of Unnes. It is then adapted to the learning climate either in class, out of class, or other student coaching activities. Everything goes structured and systematically from the highest line to the student units. This is to achieve the common goal of the form of human character or personal philosophy that is suitable for national and state philosophies, religion, culture to reach human beings who are socially and environmentally conscious. With this, the pattern is well-equipped and constantly.

\section{CONCLUSION AND SUGGESTIONS}

Based on the results of the research and discussion strategy of conservation values in the UNNES campus habituation for the establishment of student personality can be concluded that the strategy of integration values of conservation in UNNES campus is carried out through all lines of academic and non-academic activities. Planting conservation values through academic activities is evident from the educational courses of conservation, environmental education, and other courses that support and align with the values of conservation. While planting conservation values through non-academic activities is visible through the activities of UPT conservation development, student activity Unit, and Student Activities Center, including the program of planting One tree one student for the new students UNNES. Habituation to be a strategy to embed conservation values in UNNES, the personality of students has been conservative visible from the conservative behavior of students in the campus environment. With this, the student's behavior is closely related to its conservation character, so it directly reflects the actions that the parties have played in integrating and implementing the conservation values of UNNES.

\section{REFERENCES}

Allport, G. W. (1960). The open system in personality theory. The Journal of Abnormal and Social Psychology, 61(3), 301.

Dwidjoseputro, D. (1994). Human Ecology and Its Environment. Erlangga. Jakarta.

Hall, C. S., Lindzey, G., \& Campbell, J. B. (1957). Theories of personality. Wiley New York.

Handoyo, E., Si, M., Tijan, M. S., Cipta, H., Isi, R. G., Cover, D., ... Basuki, A. M. (2010). Character Education Model Based on Conservation Experience of Universitas Negeri Semarang. Semarang: Widya Karya \& UNNES., 6.

Indonesia, U.-U. R. (2003). Sistem Pendidikan Nasional. Jakarta: Direktorat Pendidikan Menengah Umum.

Miles, M. B., \& Huberman, A. M. (1994). Qualitative data analysis: An expanded sourcebook. sage.

Parsons, T. (1949). The structure of social action (Vol. 491). Free press New York.

Rachman, M. (2011). Moral educational research methods in quantitative, qualitative, mixed, action, and development approaches. Semarang: Universitas Negeri Semarang.

Richmond, A., Bracker, A., \& Bracker, A. L. (2009). Conservation: principles, dilemmas and uncomfortable truths. Routledge.

Riki, A. (2014). Community Based Conservation (Study of Universitas Negeri Semarang Branding Strategies as a Conservation University). Postgraduate Program in Communication Studies.

Saddam, S., Setyowati, D. L., \& Juhadi, J. (2016). Integration of Conservation Values in Campus Habituation for the Establishment of Student Personality at Universitas Negeri Semarang. Journal of Educational Social Studies, 5(2), 128-135.

Setyowati, D. L. (2015). The Realization of Conservation in Semarang State University Campus. Proceeding International Iccbl.

Setyowati, D. L., \& Eko Handoyo, F. I. S. (2019). Application of Conservation Value for Character Developing of Universitas Negeri Semarang Students. ISET.

Spradley, J. P. (2006). The Etnographyc Interview. Misbah Zulfa Elisabeth. Metode Etnografi. Yogyakarta: Tiara Wacana. 